What factors influence physical activity participation in people with rheumatoid arthritis?

Donna M. Riggs, Physiotherapist, Yeovil District Hospital, Yeovil, UK.

Clare Killingback, Faculty of Health Sciences, Department for Sport, Health and Exercise Science, University of Hull, UK.

Word count:

Abstract 248

Text 3027 


\section{What factors influence physical activity participation in people with rheumatoid arthritis?}

Background: Rheumatoid arthritis (RA) is a chronic autoimmune disease characterized by periods of inflammation and remission. Physical activity can reduce disease activity and lower the risks of associated co-morbidities such as cardiovascular disease. Despite the benefits, a high percentage of people with RA do not participate in regular physical activity.

Objective: The purpose of this qualitative literature review was to explore and synthesize the experiences of people with RA to develop better insight of the factors that influence physical activity participation.

Method: A systematic search was conducted across five online databases; MEDLINE, CINAHL, ScienceDirect, PsycINFO, Web of Science. Studies were assessed for quality, data were extracted and analyzed using thematic synthesis.

Results: A total of 186 articles were identified and screened against inclusion/exclusion criteria. Seven studies met the criteria and were included in this review. Five key themes were identified as the most significant factors to physical activity participation: professional knowledge and guidance; part of a community; knowing me, knowing RA; what's in it for me; and where, when, how much? Professional knowledge and guidance was the underpinning factor influencing physical activity participation.

Conclusion: The results identify several internal and external factors that affect physical activity participation. To engage, facilitate and motivate patients to participate in physical activity, ongoing education and support from health care professionals is required. This will promote better symptom management and maintain functional independence. Additionally, health care professionals need to consider individual preferences and abilities when recommending physical activity.

Keywords: Physical activity; qualitative; perspective; rheumatoid arthritis 


\section{Introduction:}

Rheumatoid arthritis (RA) is a progressive autoimmune disease affecting approximately one percent of the population [1]. Disease prevalence and severity are linked to both environmental and genetic factors [2], with women two to four times more likely to develop RA than men [3].

People with RA experience unpredictable periods of inflammation and remission [4] causing swollen and painful synovial joints, which if left untreated results in permanent joint damage, bone destruction and disability [1]. Due to the inflammatory nature of the disease, RA also increases the risk of premature mortality from comorbidities such as cardiovascular disease [5,6] As there is no cure for RA, current treatments focus on reducing disease activity and symptom management [4].

Research shows that physical activity can assist in symptom management and lower the risks of co-morbidities [7]. Yet people with RA often struggle to achieve the recommended 150 minutes of moderate intensity exercise per week [8]. Approximately $67 \%$ of people in the United Kingdom (UK) with RA were found to be physically inactive [9]. Changes to the recommendations of physical activity participation in recent years may have provided conflicting information about what is safe and appropriate for people with RA [9] and this could be a limiting factor in promoting self-management.

By understanding the physical activity experiences of individuals with RA it can be enable opportunities to educate individuals and create positive experiences of physical activity. This can be both empowering and beneficial in facilitating behavior change, which is important to increasing physical activity participation [7]

The aim of this qualitative literature review was to explore the experiences of physical activity participation in people with RA in order to identify factors that can promote and support physical activity participation.

\section{Methods}

\subsection{Search strategy}


A systematic search was conducted across five online databases (MEDLINE, CINAHL, ScienceDirect, PsycINFO, Web of Science). No date limitation was placed on the search. Records were searched to 11 November 2017. Using a Boolean search strategy, key terms (e.g. 'belief', 'exercise', 'rheumatoid arthritis', 'qualitative') and their alternatives were entered into the databases (Table 1). Articles identified by the search were initially screened by title and abstract. Full texts were then assessed for eligibility against the inclusion and exclusion criteria (Table 2). The search was limited to peer reviewed journals and restricted to articles published in English. There was no limitation placed on geographical region or study date as emphasis was on patient perspective, therefore any findings meeting the criteria were deemed relevant.

\subsection{Inclusion and exclusion criteria}

Qualitative and mixed methods studies were included. Studies needed to report clearly on the patient perspectives in relation to their understanding and experiences of physical activity. Studies where people did not already participate in physical activity were not excluded, as they may provide insight into the factors that limit physical activity. Papers were excluded if perspectives were not the patient's, the data was not specific to RA or if the type of arthritis was not specified.

\subsection{Data extraction}

Data were extracted by one author (DR) and arranged into a customized table (Table 3) using the following headings: study aims, study design, sample population, criteria and themes. A three-stage thematic synthesis was completed, based on methods used by Thomas and Harden [10]; line by line coding, developing descriptive themes and generating analytical themes. Initial stages were completed by extracting quotations from participants and coding them according to their meaning. From the extracted quotes broad themes were identified across all studies based on similarities. Codes were reviewed to ensure they accurately reflected the participants views in the original papers. The descriptive themes were used to establish key meanings and create new ideas which addressed the question of the review.

\subsection{Quality assessment}


Quality was assessed using the Critical Appraisal Skills Programme (CASP) qualitative checklist [11]. A numerical scoring system (yes=2, can't tell=1, no=0) was awarded against the ten checklist questions resulting in each study obtaining a score out of 20. The number of authors who contributed to data collection varied throughout the included studies. Two papers $[17,18]$ had two contributing authors, two others had three $[13,16]$ and a further two studies used four authors [14,19] for data collection. The remaining study [15] involved all five authors. To aid quality, one study was directed by the checklist of consolidated criteria for reporting qualitative research [19]. Other studies used other authors $[13,14,15,18]$ or independent individuals [16] to re-analyse themes. Consensus of themes throughout were reached via discussion and challenging ideas until agreement was reached.

\section{Results}

\subsection{Included studies}

A total of 186 articles were identified and screened against inclusion and exclusion criteria. seven studies met the inclusion criteria and were included in this review. Fig. 1 presents a flow chart of study selection adapted from Preferred Reporting Items for Systematic review and Meta-Analyses (PRISMA) [12].

\subsection{Study characteristics}

Data were collected via focus groups or semi structured interviews either faceto-face or via the telephone. Data analysis consisted of general inductive approach, [13$15]$ systematic text condensation $[16,17]$ or thematic analysis $[18,19]$.

Study size varied from eight to nineteen with a total of 106 participants across the seven papers. One study included only female participants [14] the other six included male and female participants. Participants were enrolled via self-referral in one study [17] whilst the remaining six recruited patients attending outpatient rheumatology or physiotherapy clinics. Three studies [16-18] involved participants who participated in physical activity, one study [13] had a mixture of active and non-active patients and the other two studies did not specify physical activity level.

Participants in all seven studies had a diagnosis of RA. Four of the studies $[13,15,18,19]$ recorded a diagnosis in accordance with the rheumatoid arthritis 
classification criteria [20,21], one study [14] had a diagnosis by a rheumatology consultant and two articles did not specify how a diagnosis of RA had been made.

Geographically, the studies were carried out in; Denmark [17], Ireland [19], Sweden [16,18] the UK [13,15] and New Zealand [14]. Study characteristics are detailed in Table 3.

\subsection{Quality of included studies}

Purposefully collected personal perspectives offered with qualitative studies offer valuable and diverse contributions to research, especially in health-related topics [22]. It is suggested that the quality of qualitative studies should be assessed by appropriateness of the design and methods used to address the research question [22]. Consistency between data collection and analysis increase rigor [22] and can be assessed using the CASP checklist. All of the studies scored $\geq 16$ on the CASP checklist [11]. Main limitations were lack of clear ethical approval $[16,18]$ and difficulties recognizing if the relationship between researcher and participants had been adequately considered. No studies were excluded based on quality.

\subsection{Qualitative synthesis}

Following the three-stage thematic synthesis [10] five themes were identified as the most significant factors to physical activity participation: professional knowledge and guidance; part of a community; knowing me, knowing RA; what's in it for me; and where, when, how much? Knowledge and guidance from health care professionals was the overriding factor influencing physical activity participation. Findings are illustrated in Fig.2.

\subsubsection{Professional knowledge and guidance}

All seven studies highlighted the importance of ongoing support from healthcare professionals. Key features included providing advice and information about RA and encouraging patients to be confident undertaking activity. Not understanding what was meant by physical activity was a common factor, "The doctor said something about staying active, but she didn't say what..." [14,p.777]. This often coincided with fear of causing damage or pain $[14,15,18,19]$. 
Patients expressed the views that physical activity should be prescribed by a healthcare professional $[14,18]$, who should use their expertise to implement safe, effective exercises [19]. Despite this, three studies [13,14,19] highlighted that although overloaded with RA information, health care professionals appeared to lack knowledge of physical activity "I have asked the doctors and they just say do as much as you can" [14,p.776].

Health care professionals were considered a source of monitoring and motivation [15-18] which was noted as being significant to the success of physical activity programs [15]. Supervised classes were favorable overall $[15,18]$ whist home exercise plans were considered manageable with support such as follow-up appointments [18] or via the telephone [19].

\subsubsection{Part of a community}

Six studies reported on social connections being a key factor to undertaking physical activity. A reported sense of "belonging to a community" and "sharing the same struggles" [17,p.294] indicating that acceptance and understanding were important. Groups offered motivation and practical support for managing RA based on personal experience [15].

Whilst social interaction facilitated most participants, others felt that being part of an RA group labelled them as an RA patient and took away their identity $[15,17]$. One person reported “...for me it is important to be with ordinary people" [17,p.294]. Meeting people who had more advanced stages of RA evoked mixed emotions; intimidation, fear and motivation $[15,16]$. A desire to limit disease progression, alongside seeing the benefits in others with RA endorsed participation $[15,16]$.

\subsubsection{Knowing me, knowing $R A$}

Pain and fatigue were consistently identified as barriers to staying active [13,15-17] and caused uncertainty as to whether activity was appropriate or would make symptoms worse [14]. Unpredictability of RA provoked safety fears, causing tension between concerned loved ones. Despite this, patients felt it was "worth the risk" [13] and used physical activity as a way of taking control. 
Patients accepted their role in managing their condition but highlighted the need for support "I have my responsibility, but I must be able to get guidance..." [18]. For some physical activity was a "duty" [13] whilst others considered it part of the management plan. One person stated, "I am just considering physical activity as a supplement to medication" [17,p.293].

Improved self-awareness through activity enabled patients to acquire better understanding of their symptoms and limitations [17].

Consequentially, this enhanced self-efficacy and increased ability to cope with unpredictable "flare ups" [17].

\subsubsection{What's in it for me?}

Physical and mental benefits of physical activity were a prevalent factor across five of the studies. Patients reported increased strength, reduced pain and improved mobility $[13,16]$. This enhanced function in everyday life "It becomes easier to get up from a chair..." [17,p.293].

Promoting mental wellbeing was another recognized benefit. Physical activity evoked feelings of pleasure and pride [17] which were necessary for prolonged commitment. Participation in physical activity gave patients the satisfaction that they were accomplishing "wellness rather than illness" [16,p.283].

Inactivity was associated with an increase in pain and stiffness [19] as well as a fear of reduced mobility [13]. The fundamental incentive for patients was to counteract disease progression and preserve independence [16], maintaining both self-identity and role within society [17].

\subsubsection{Where, when, how much?}

Though not consistent in every study, practicalities such as location, cost, weather and time were prime considerations. Lifestyle constraints such as children and employment also had an impact [15], therefore patients preferred activity that fitted into their daily routines "I don't take the car...I take the bicycle... then I sort of get it for free." [16,p.287] 
Some patients described more flexibility when undertaking physical activity at home [18], however lack of motivation or discipline led to a preference of pre-arranged activity over home-based programs $[15,18,19]$. Regarding location, community settings were preferred as they removed the stigma of being "a patient, rather than a person with RA” [19,p.1684] which was negatively associated with the hospital setting.

\section{Discussion}

The aim of this review was to explore the experiences of physical activity participation in people with RA and five key contributions emerged as a direct result. The themes highlight a need to gain knowledge and acceptance both from patients themselves and those around them. This helped maintain their roles within society.

Firstly, this review highlights the need for ongoing health care professional knowledge and guidance as this appeared to impact the most on physical activity participation throughout all included studies. Evidence from a systematic review by Hurkmans [23] showed that both land and water-based exercises are safe and effective for people with RA. However, four of the studies in this review stated that pain and fear of damage through inappropriate physical activity were one of the biggest factors influencing participation, highlighting a mismatch between patient views and the evidence base on what is safe and appropriate with regards physical activity.

Patients expressed the desire for clearer guidance regarding the type of activity to undertake but felt that health care professionals lacked the knowledge to deliver this confidently. This view was echoed by healthcare professionals who felt that while they recognized the benefits of keeping physically active, they had not received appropriate exercise prescription training or did not consider its delivery to be part of their role $[24,25]$. This highlights a possible difference in priorities between health care professionals and patients [24]. This suggests that further education is required to deliver education and advice to patients, something which should be provided as part of their management plan in accordance with National Institute for Health and Care Excellence guidelines (NICE) [26].

Once participating in physical activity, participants appeared to seek continued support, including motivational support from health care professionals. Some patients 
preferred to access this via supervised groups, while others felt they could manage with supported home programs, both of which have comparable adherence rates providing there is some form of continued monitoring [27]. Evidence suggests that regular activity increases self-efficacy [28] therefore, those patients who regularly participate in physical activity are likely to require less external input [27].

The second contribution this current study makes to understanding experiences of those who have RA is the impact of social interaction. This was a preference for group activities amongst participants. Literature suggests that those in their 40's and 50 's tend to prefer being in groups [29] and this may explain why, with an average age of 58 years, it was favored by patients in this review. Whilst the above study was not RA specific, the results were consistent with the similarity-attraction hypothesis [29], suggesting that people are attracted to those similar to themselves. Therefore, the results could still be relevant to RA groups. This was demonstrated by the patients in this review who bonded over common struggles [19]. In support of this, the results of a meta-analysis by Burke et al. [27] show that social interaction can promote initiation and satisfaction of physical activity.

In contrast, this review discovered a differing opinion with some participants who did not want to be labelled as someone with RA. Other studies express the desire for people with RA to lead "normal lives" [30,31] and physical activity could be a way of achieving this. Some may not classify themselves as being in the same situation as others in the group [29] and do not want to be confronted with more advanced cases of RA. Clearly not everyone wants to belong to an RA community, demonstrating the need to consider personal preferences when encouraging participation.

Thirdly, participants acknowledge that managing RA is a shared responsibility, an idea supported by NICE [26]. However, professionals need to play their part to empower those with RA to make the changes needed to enhance the management of their condition [32]. This idea complements that of the partnership paradigm [33] whereby patients become the experts.

Physical activity increased participants body awareness and built confidence in their abilities. This enabled them to adapt activities in response to their condition, especially symptoms such as pain and fatigue, which as similarly reported in other studies often presented as a barrier to participation [34,35]. This heightened self- 
awareness permits those with RA to remain active, promoting general health benefits such as weight management as well as reducing the risks of associated co-morbidities, such as cardiovascular disease [5]. This not only impacts upon quality of life for but may also bring about positive financial implications for healthcare services [36].

In contrast to other literature [35] some acknowledged that physical activity helped to rationalize and validate their symptoms [17]. People achieving regular physical activity formed coping strategies, making them better equipped to deal with the unpredictable nature of RA [31], thus reducing the stress to loved ones [13]. This is important for overall wellbeing which in turn can reduce pain [35].

Fourthly, the physical benefits of physical activity for people with RA is well researched $[23,35]$. Resistance and aerobic training have been proven to reduce inflammation and improve fitness, strength and flexibility [35]. This correlates with the benefits experienced by participants in this review, shown by enhanced function in daily living, a key incentive for increased participation.

Positive feelings endorsed the psychological impact of staying active and helped participants develop a sense of achievement. They could understand their RA, possibly through enhanced coping strategies [31]. As such, they could make the necessary adjustments to live with RA without losing purpose, resulting in an increased sense of wellness [37].

Health care professionals should take a holistic approach, inspiring individuals with RA to increase physical activity levels by letting them know "what's in it for them". Interestingly, none of the studies in this review reported on the benefits against associated co-morbidities. This differs to the quantitative findings of Henchoz et al. [34], who found participants were aware of the added risks. Although it is unclear whether this was due to a lack of awareness or outside of the scope of the studies included in this review.

Finally, activities need to be accessible in terms of time, cost and location [15]. This was echoed by others when $51.6 \%$ of participants reported scheduling to be a barrier to physical activity attendance [38]. Home exercises provided flexibility but often there was a lack of motivation to pursue them, making them less effective [27]. In 
addition, professionally led physical activity held within a community setting was preferred to hospital-based classes. Participants felt this was more accessible and enabled them to build confidence in their abilities away from a clinical setting which is important for long term engagement, especially when following on from an initial hospital-based program [18].

\subsection{Strengths and limitations}

This review offers qualitative insight to the key factors that influence physical activity levels amongst people with RA. Addressing these factors may increase physical activity participation and retention which can lead to better long-term management of RA. Limitations of this review include the fact that studies were limited to those published in English and no grey literature was included. Reference lists of included studies were not screened for additional references; therefore, some relevant articles may have been omitted. Participant activity levels is not apparent in every study and views may differ depending on current physical activity intensity and disease severity. The studies were from similar socio-economic countries; therefore, attitudes may differ in cultures where physical activity is not recognized as part of a management plan.

\section{Conclusion}

This review sought to explore the experiences of people with RA to develop better insight into the factors that influence physical activity participation. Based on the findings this review identified five key areas.

Ongoing education and support is required to engage, facilitate and motivate those with RA to participate in physical activity. This will help promote better symptom management for people who are often striving for independence and normality. Additionally, health care professionals need consider accessibility, group dynamics and individual preferences when recommending activity. 
There is some evidence to suggest that despite advocating its benefits, health care professionals lack knowledge around physical activity prescription, therefore further education would be beneficial.

More research to evaluate the differences in perspective between those who already engage in physical activity and those who do not may help guide future interventions in order to maximize participation.

\section{Conflict of interest}

The author declares there is no conflict of interest.

\section{About the authors}

Donna Riggs- Donna graduated from Bournemouth University in 2018. She enjoyed learning about qualitative research and how it can be used to develop and enhance practice. Donna is currently a rotational physiotherapist at Yeovil District Hospital in Somerset.

Dr Clare Killingback- Since graduating as a physiotherapist from the University of Nottingham (1999), Clare has worked in various NHS trusts. Clare has also worked in some of the more remote corners of the world including Nepal, East Timor, Afghanistan, Myanmar, Egypt, and Iraq. This has taught her to be a creative and flexible practitioner. She is now setting up the physiotherapy programme at the University of Hull. Her research interests lie in the areas of physical activity, social isolation, older people and pedagogy. She is passionate about helping the next generation of physiotherapists become excellent in utilising evidence-based practice.

Clare is a Senior Physiotherapy Lecturer and Programme Lead at the University of Hull. 


\section{References}

[1] Humphreys JH, Verstappen SMM, Hyrich KL, et al. The incidence of rheumatoid arthritis in the UK: comparisons using the 2010 ACR/EULAR classification criteria and the 1987 ACR classification criteria. Results from the Norfolk Arthritis Register. Annals of the Rheumatic Diseases 2013;72:1315-1320.

[2] Alamanos Y, Drosos AA. Epidemiology of adult rheumatoid arthritis. Autoimmunity reviews. 2005;4(3):130-136.

[3] Birch JT, Bhattacharya S. Emerging trends in diagnosis and treatment of rheumatoid arthritis. Primary care: clinics in office practice. 2010;37(4):779-792.

[4] Scott DL, Wolfe F, Huizinga TWJ. Rheumatoid arthritis. The Lancet. 2010;376(9746): $1094-1108$.

[5] Lévy L, Fautrel B, Barnetche T, et al. Incidence and risk of fatal myocardial infarction and stroke events in rheumatoid arthritis patients. A systematic review of the literature. Clinical and experimental rheumatology. 2008;26(4):673-9.

[6] Thomsen T, Beyer N, AAdahl M, et al. Sedentary behaviour in patients with rheumatoid arthritis: A qualitative study. International journal of qualitative studies on health and well-being. 2015;10(0):1-10.

[7] Knittle K, De Gucht V, Maes S. Lifestyle and behaviour-change interventions in musculoskeletal conditions. Best practice \& research clinical rheumatology. 2012;26(3):293-304.

[8] Department of Health. Start Active, Stay Active: A report on physical activity from the four home countries' chief medical officers. London: Department of Health;2011.

[9] Sokka T, Häkkinen A, Kautiainen H, et al. Physical inactivity in patients with rheumatoid arthritis: data from twenty-one countries in a cross-sectional, international study. Arthritis and rheumatism. 2008;59(1):42-50.

[10] Thomas J, Harden A. Methods for thematic synthesis of qualitative research in systematic reviews. Biomedical central medical research methodology. 2008;8(1):1-10.

[11] Critical Appraisal Skills Programme (CASP)[Internet]. Oxford: CASP, 2017 [cited 15 November 2017]. Available from: http://www.casp-uk.net/casp-tools-checklists. 
[12] Moher D, Liberati A, Tetzlaff J, et al. Preferred reporting items for systematic reviews and meta-analyses: The PRISMA Statement. International journal of surgery. 2010;8:336-341.

[13] Law R, Breslin A, Oliver EJ, et al. Perceptions of the effects of exercise on joint health in rheumatoid arthritis patients. Rheumatology. 2010;49(12):2444-2451.

[14] Baxter S, Smith C, Treharne G, et al. What are the perceived barriers, facilitators and attitudes to exercise for women with rheumatoid arthritis? A qualitative study. Disability and rehabilitation. 2016;38(8):773- 780.

[15] Withall J, Haase AM, Walsh NE, et al. Physical activity engagement in early rheumatoid arthritis: a qualitative study to inform intervention development.

Physiotherapy. 2016;102: 264-271.

[16] Kamwendo K, Askenbom M, Wahlgren C. Physical activity in the life of the patient with rheumatoid arthritis. Physiotherapy research international. 1999;4 (4):278292.

[17] Loeppenthin K, Esbensen BA, Ostergaard M, et al. Physical activity maintenance in patients with rheumatoid arthritis: A qualitative study. Clinical rehabilitation. 2014;28(3):289-299.

[18] Swärdh E, Biguet G, Opava, CH. Views on exercise maintenance: variations among patients with rheumatoid arthritis. Physical therapy. 2008;88(9):1049-1060.

[19] Larkin, L, Kennedy N, Fraser A, et al. It might hurt, but still it's good: People with rheumatoid arthritis beliefs and expectations about physical activity interventions. Journal of health psychology. 2017;22(13):1678-1690.

[20] Arnett FC, Edworthy SM, Bloch DA, et al. The American Rheumatism Association 1987 revised criteria for the classification of rheumatoid arthritis. Arthritis and rheumatism. 1988;31(3):315-324.

[21] Aletaha D, Neogi T, Silman AJ, et al. Rheumatoid arthritis classification criteria. Arthritis rheumatism. 2010;62(9):2569-2581.

[22] Leung L. Validity, reliability, and generalizability in qualitative research. Journal of family medicine and primary care. 2015;4(3):324-327. 
[23] Hurkmans E, Van der Giesen FJ, Vliet Vlieland TP, et al. Dynamic exercise programs (aerobic capacity and/or muscle strength training) in patients with rheumatoid arthritis. Cochrane database of systematic reviews. 2009;4.

[24] Lambert BL, Butin DN, Moran D, et al. Arthritis care: Comparison of physicians' and patients' views. Seminars in arthritis and rheumatism. 2000;30(2):100-110.

[25] LillieK, Ryan S, Adams J. The educational needs of nurses and allied healthcare professionals caring for people with arthritis: results from a cross-sectional survey. Musculoskeletal care. 2013;11:93-98.

[26] National Institute for Health and Care Excellence. Rheumatoid arthritis in adults: management. CG79. London: National Institute for Health and Care Excellence; 2009.

[27] Burke SM, Carron AV, Eys MA, et al. Group versus individual approach? A metaanalysis of the effectiveness of interventions to promote physical activity. Sport and exercise psychology review. 2006;2(1):19-35.

[28] Hurkmans E, Maes S, De Gucht V, et al. Motivation as a determinant of physical activity in patients with rheumatoid arthritis. Arthritis care and research. 2010;62:371377.

[29] Beauchamp MR, Carron AV, McCutcheon S, et al. Older adults' preferences for exercising alone versus in groups: considering contextual congruence. Annals of Behavioral Medicine: A publication of the society of behavioral medicine. 2007;33(2):200-206.

[30] Lempp H, Scott D, Kingsley G. The personal impact of rheumatoid arthritis on patients' identity: a qualitative study. Chronic illness. 2006;2(1):109-120.

[31] Grønning K, Lomundal B, Koksvik HS, et al. Coping with arthritis is experienced as a dynamic balancing process: A qualitative study. Clinical rheumatology. 2011;30:1425-1432.

[32] Aujoulat I, Marcolongo R, Bonadiman L, et al. Reconsidering patient empowerment in chronic illness: a critique of models of self-efficacy and bodily control. Social science and medicine. 2008;66(5):1228-1239. 
[33] Bodenheimer T, Lorig K, Holman H, et al. Patient self-management of chronic disease in primary care. Journal of the American medical association.

2002;288(19):2469-2475.

[34] Henchoz Y, Zufferey P, So A. Stages of change, barriers, benefits, and preferences for exercise in RA patients: a cross-sectional study. Scandinavian journal of rheumatology. 2013;42(2):136-145.

[35] Verhoeven F, Tordi N, Prati C, et al. Physical activity in patients with rheumatoid arthritis. Joint bone spine. 2016;83:265-270.

[36] Kings fund [online]. London: Kings fund, 2010 [cited 28 December 2017].

Available from:

https://www.kingsfund.org.uk/sites/default/files/field/field_document/managing-peoplelong-term-conditions-gp-inquiry-research-paper-mar11.pdf

[37] Sanderson T, Morris M, Calnan M, et al. It's this whole picture, this well-being: patients' understanding of feeling well with rheumatoid arthritis. Chronic illness. 2010;6(1):228-240.

[38] Brittain DR, Gyurcsik NC, McElroy M, et al. General and arthritis-specific barriers to moderate physical activity in women with arthritis. Women's health issues. 2011;21(1):57-63. 
Table 1. Search terms applied

\begin{tabular}{|l|l|}
\hline Key search term & Alternatives \\
\hline View* & Experience* \\
& Belief* \\
& $\begin{array}{l}\text { Perception* } \\
\text { Attitude* } \\
\text { Perspective* }\end{array}$ \\
\hline \multirow{3}{*}{ AND Physical activit** } & $\begin{array}{l}\text { Sport } \\
\text { Exercise* } \\
\text { Fitness } \\
\text { Aerobic training } \\
\text { Strength training } \\
\text { Cardiovascular training }\end{array}$ \\
\hline \multirow{2}{*}{$\begin{array}{l}\text { AND Rheumatoid } \\
\text { arthritis }\end{array}$} & $\begin{array}{l}\text { RA } \\
\text { Arthritis }\end{array}$ \\
\hline AND Qualitative & Mixed method* \\
& \\
\hline
\end{tabular}

* represents addition characters used in truncation.

Table 2. Inclusion/exclusion criteria for study selection

\begin{tabular}{|c|c|}
\hline Inclusion Criteria & Exclusion Criteria \\
\hline $\begin{array}{l}\text { - Qualitative or mixed methods } \\
\text { methodology } \\
\text { - Adults (18 years }+ \text { ) with a diagnosis } \\
\text { of rheumatoid arthritis } \\
\text { - Peer reviewed studies published in } \\
\text { English }\end{array}$ & $\begin{array}{l}\text { - } \text { Perspectives of anyone other than the } \\
\text { - } \text { patient } \\
\text { - } \text { Grey literature } \\
\text { - Studies not printed in English } \\
\text { Studies where the type of arthritis } \\
\text { was not clearly defined. }\end{array}$ \\
\hline
\end{tabular}


$19 \mid \mathrm{P}$ a g e 
Table 3. Study characteristics of included studies.

\begin{tabular}{|c|c|c|c|c|c|c|}
\hline Study & Aims & Quality & Design & Population & Criteria & Themes \\
\hline $\begin{array}{l}\text { Kamwendo } \\
\text { et al. (1999) }\end{array}$ & $\begin{array}{l}\text { To achieve a better } \\
\text { understanding of } \\
\text { how patients with } \\
\text { RA perceive and } \\
\text { relate to physical } \\
\text { activity in their } \\
\text { everyday lives. }\end{array}$ & $16 / 20$ & $\begin{array}{l}\text { Qualitative design } \\
\text { using semi } \\
\text { structured } \\
\text { interviews. }\end{array}$ & $\begin{array}{l}\text { Sample size: } 10 \\
\text { Gender: Male (4) and female } \\
\text { (6) } \\
\text { Age: } 42-68 \text { years } \\
\text { Disease duration: } 1-28 \text { years } \\
\text { Employment status: } \\
\text { Employed (3), sick leave (2), } \\
\text { pensioners (5). } \\
\text { Setting: Outpatient centres, } \\
\text { Sweden } \\
\text { Sample selection: } \\
\text { Consecutive sample of } \\
\text { patients with RA who had } \\
\text { attended an outpatient clinic } \\
\text { during the previous } 2 \\
\text { months. }\end{array}$ & $\begin{array}{l}\text { Diagnosis of } \\
\text { RA. } \\
\text { Walking, } \\
\text { cycling or } \\
\text { working in the } \\
\text { home- (patient } \\
\text { choice of } \\
\text { activity). }\end{array}$ & $\begin{array}{ll}\text { - } & \text { Driving force } \\
\text { - } & \text { Hindrance } \\
\text { - } & \text { Physical activity }\end{array}$ \\
\hline $\begin{array}{l}\text { Swärdh et } \\
\text { al. (2008) }\end{array}$ & $\begin{array}{l}\text { To explore and } \\
\text { describe ways of } \\
\text { understanding } \\
\text { exercise } \\
\text { maintenance } \\
\text { amongst patients } \\
\text { with RA who have } \\
\text { already started to } \\
\text { exercise. }\end{array}$ & $18 / 20$ & $\begin{array}{l}\text { Qualitative design } \\
\text { using semi } \\
\text { structured } \\
\text { interviews. }\end{array}$ & $\begin{array}{l}\text { Sample size: } 18 \\
\text { Gender: Male (4) and } \\
\text { Female (14) } \\
\text { Age: } 34-83 \text { years } \\
\text { Disease duration: } 3-53 \text { years } \\
\text { Employment status: } \\
\text { Employed (5), sick leave (4) } \\
\text { pensioner (9) } \\
\text { Setting: Clinics or patients' } \\
\text { work place, Sweden }\end{array}$ & $\begin{array}{l}\text { Diagnosis of } \\
\text { Ra } \\
\text { Exercising 2+ } \\
\text { times a week } \\
\text { (either } \\
\text { organised } \\
\text { activity or } \\
\text { home-based } \\
\text { exercises). }\end{array}$ & $\begin{array}{ll}\text { - } & \text { External control } \\
\text { - Sticks and carrots- } \\
\text { (support/guidance) } \\
\text { - Joint venture } \\
\text { (inspiration/ } \\
\text { variation) } \\
\text { - The easy way } \\
\text { (professional } \\
\text { support) } \\
\text { - One's own terms }\end{array}$ \\
\hline
\end{tabular}




\begin{tabular}{|c|c|c|c|c|c|c|}
\hline Study & Aims & Quality & Design & Population & Criteria & Themes \\
\hline & & & & $\begin{array}{l}\text { Sample selection: Purposeful } \\
\text { selection from } 4 \text { hospital or } \\
\text { primary care physical } \\
\text { therapy clinics. }\end{array}$ & & \\
\hline $\begin{array}{l}\text { Law et al. } \\
\text { (2010) }\end{array}$ & $\begin{array}{l}\text { To explore } \\
\text { perceptions of } \\
\text { patients with RA } \\
\text { regarding the } \\
\text { effects of exercise } \\
\text { on joint health. }\end{array}$ & $18 / 20$ & $\begin{array}{l}\text { Qualitative design } \\
\text { using focus } \\
\text { groups. }\end{array}$ & $\begin{array}{l}\text { Sample size: } 18 \\
\text { Gender: Male (6) and } \\
\text { Female (12) } \\
\text { Age: } 23-76 \text { years } \\
\text { Disease duration: } 2.5 \\
\text { months- } 33 \text { years } \\
\text { Employment status: Not } \\
\text { specified } \\
\text { Setting: Bangor University } \\
\text { Sample selection: Purposeful } \\
\text { selection from Department of } \\
\text { Rheumatology, Betsi } \\
\text { Cadwaladr University Health } \\
\text { Board. }\end{array}$ & $\begin{array}{l}\text { Under MDT } \\
\text { rheumatology } \\
\text { care and } \\
\text { offered } \\
\text { Rheumatology } \\
\text { Exercise } \\
\text { Programme } \\
\text { (REPS). }\end{array}$ & 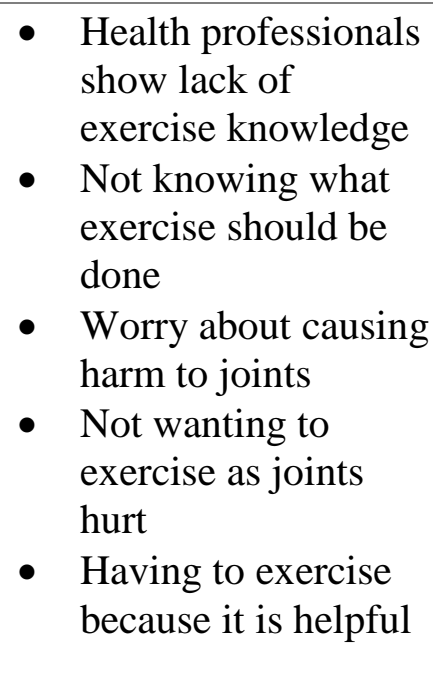 \\
\hline $\begin{array}{l}\text { Loeppenthi } \\
\text { n et al. } \\
(2014)\end{array}$ & $\begin{array}{l}\text { To describe the } \\
\text { experience of } \\
\text { physical activity } \\
\text { maintenance in } \\
\text { patients with RA. }\end{array}$ & $16 / 20$ & $\begin{array}{l}\text { Qualitative design } \\
\text { using semi } \\
\text { structured } \\
\text { interviews. }\end{array}$ & $\begin{array}{l}\text { Sample size: } 16 \\
\text { Gender: Male (4) and } \\
\text { Female (12) } \\
\text { Age: } 37-67 \text { years } \\
\text { Disease duration: } 4-46 \text { years } \\
\text { Employment status: } \\
\text { Employed (9), unemployed } \\
\text { (2), retired (5). }\end{array}$ & $\begin{array}{l}1 \text { year }+ \\
\text { diagnosis of } \\
\text { RA and } \\
\text { participating } \\
\text { in regular } \\
\text { physical } \\
\text { activity for }> \\
\text { six months. }\end{array}$ & $\begin{array}{ll}\text { - } & \text { Knowing and } \\
\text { enjoying the body } \\
\text { - } & \text { Responsibility and } \\
\text { challenges }\end{array}$ \\
\hline
\end{tabular}




\begin{tabular}{|c|c|c|c|c|c|c|}
\hline Study & Aims & Quality & Design & Population & Criteria & Themes \\
\hline & & & & $\begin{array}{l}\text { Setting: Patients home or } \\
\text { authors office in Denmark. } \\
\text { Sample selection: Self- } \\
\text { referral open invitations } \\
\text { accessed via Danish } \\
\text { Rheumatism Association or } \\
\text { Outpatient Clinic of } \\
\text { Rheumatology. }\end{array}$ & & \\
\hline $\begin{array}{l}\text { Baxter et } \\
\text { al. (2016) }\end{array}$ & $\begin{array}{l}\text { To explore the } \\
\text { perceived barriers, } \\
\text { facilitators and } \\
\text { attitudes to } \\
\text { exercise in people } \\
\text { with RA. }\end{array}$ & $19 / 20$ & $\begin{array}{l}\text { Qualitative design } \\
\text { using semi } \\
\text { structured } \\
\text { interviews via } \\
\text { telephone/ skype. }\end{array}$ & $\begin{array}{l}\text { Sample size: } 8 \\
\text { Gender: Female (8) } \\
\text { Age: } 56-82 \text { years } \\
\text { Disease duration: } 5-29 \text { years } \\
\text { Employment status: } \\
\text { Employed (6), unemployed } \\
\text { (2). } \\
\text { Setting: New Zealand. } \\
\text { Sample selection: } \\
\text { Convenience sample from } \\
\text { outpatient rheumatology } \\
\text { clinic of public hospital. }\end{array}$ & $\begin{array}{l}\text { Diagnosis of } \\
\text { RA and able } \\
\text { to walk } 200 \mathrm{~m} \\
\text { unassisted. }\end{array}$ & $\begin{array}{l}\text { - Social connections } \\
\text { - Fear (of unknown, } \\
\text { known and for } \\
\text { safety) }\end{array}$ \\
\hline $\begin{array}{l}\text { Withall et } \\
\text { al. (2016) }\end{array}$ & $\begin{array}{l}\text { To understand } \\
\text { motivators and } \\
\text { facilitators in } \\
\text { engagement of } \\
\text { physical activity, } \\
\text { identify key factors }\end{array}$ & $17 / 20$ & $\begin{array}{l}\text { Qualitative design } \\
\text { using semi } \\
\text { structured focus } \\
\text { groups. }\end{array}$ & $\begin{array}{l}\text { Sample size: } 19 \\
\text { Gender: Male (4) and } \\
\text { Female (15) } \\
\text { Age: } 31-73 \text { years } \\
\text { Disease duration: } 1 \text { month- } \\
10 \text { years }\end{array}$ & $\begin{array}{l}18 \text { years }+ \\
\text { with diagnosis } \\
\text { of RA within } \\
\text { past } 5 \text { years. }\end{array}$ & $\begin{array}{l}\text { - Why people join } \\
\text { exercise groups and } \\
\text { why they drop out } \\
\text { - Venue and timing } \\
\text { - What do people want } \\
\text { to do and hear? }\end{array}$ \\
\hline
\end{tabular}




\begin{tabular}{|c|c|c|c|c|c|c|}
\hline Study & Aims & Quality & Design & Population & Criteria & Themes \\
\hline & $\begin{array}{l}\text { that may affect } \\
\text { recruitment and } \\
\text { retention to } \\
\text { exercise } \\
\text { programmes and } \\
\text { explore patient } \\
\text { perceptions on } \\
\text { physical activity } \\
\text { programmes. }\end{array}$ & & & $\begin{array}{l}\text { Employment status: } \\
\text { Employed (8), unemployed } \\
\text { (1), retired (10) } \\
\text { Setting: University Hospitals } \\
\text { Bristol NHS Foundation } \\
\text { Trust and the Royal National } \\
\text { Hospital for Rheumatic } \\
\text { Diseases, Bath. UK. } \\
\text { Sample selection: Purposeful } \\
\text { sample selected from } \\
\text { Rheumatology clinics. }\end{array}$ & & $\begin{array}{l}\text { - Who should deliver } \\
\text { the programme and } \\
\text { how }\end{array}$ \\
\hline $\begin{array}{l}\text { Larkin et } \\
\text { al. (2017) }\end{array}$ & $\begin{array}{l}\text { To gain insight as } \\
\text { to how people with } \\
\text { RA view physical } \\
\text { activity (to inform } \\
\text { design of future } \\
\text { physical activity } \\
\text { intervention) and } \\
\text { explore how their } \\
\text { levels of activity } \\
\text { may be increased. }\end{array}$ & $19 / 20$ & $\begin{array}{l}\text { Qualitative design } \\
\text { using semi } \\
\text { structured } \\
\text { interviews via } \\
\text { telephone. }\end{array}$ & $\begin{array}{l}\text { Sample size: } 17 \\
\text { Gender: Male (5) and } \\
\text { Female (12) } \\
\text { Age: } 35-83 \text { years } \\
\text { Disease duration: } 1-47 \text { years } \\
\text { Employment status: Not } \\
\text { specified } \\
\text { Setting: Urban hospital in } \\
\text { Mid-west region of Ireland } \\
\text { Sample selection: Purposeful } \\
\text { sample selected from } \\
\text { patients attending routine } \\
\text { outpatient appointments at } \\
\text { rheumatology clinic. }\end{array}$ & $\begin{array}{l}\text { Aged 18+ } \\
\text { with diagnosis } \\
\text { of RA. }\end{array}$ & $\begin{array}{l}\text { - Being active } \\
\text { - Barriers and } \\
\text { facilitators } \\
\text { - Advice and } \\
\text { information } \\
\text { - Supporting physical } \\
\text { activity }\end{array}$ \\
\hline
\end{tabular}


Figure 1. Study selection flow chart.

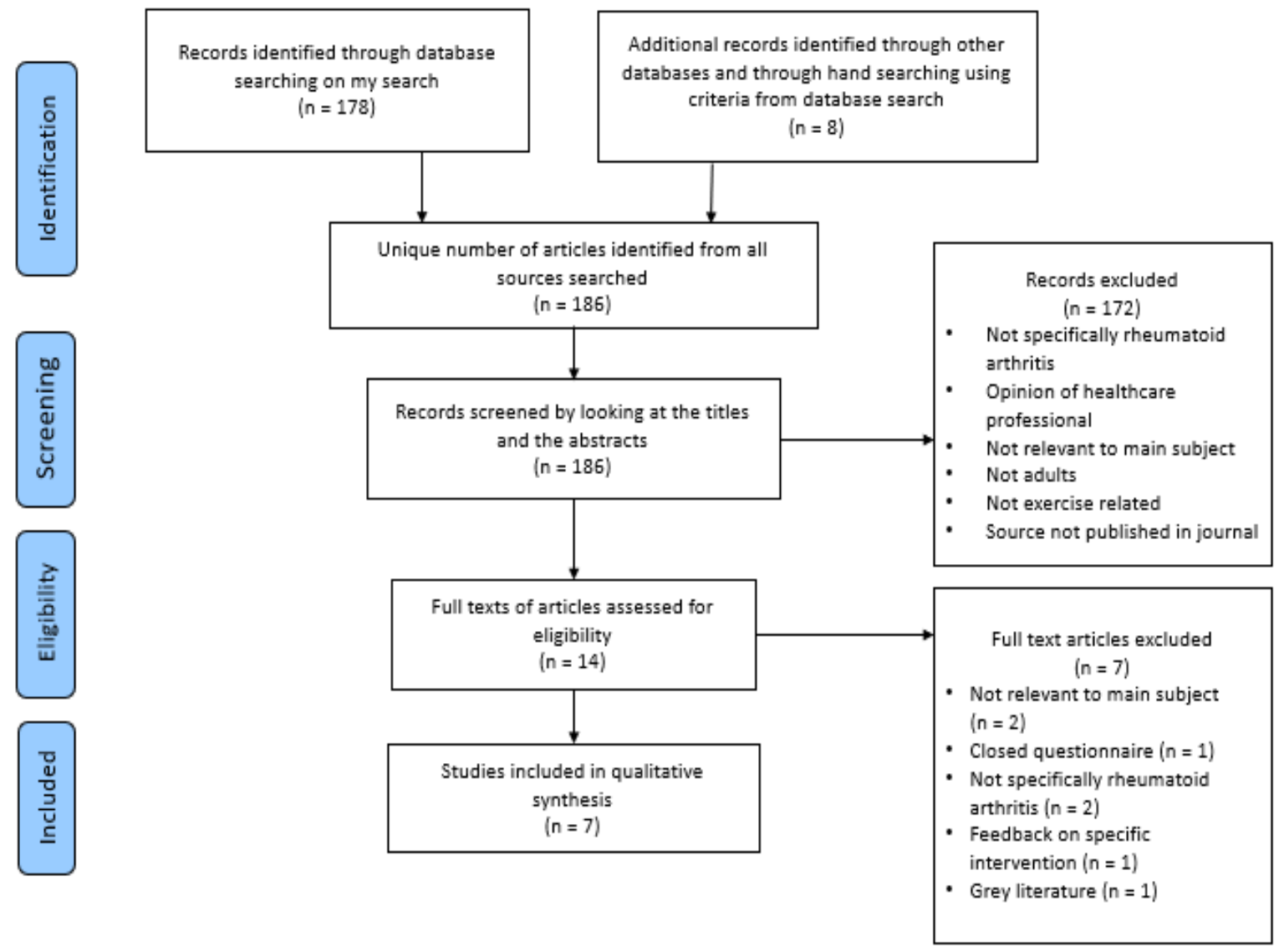


Figure 2. Thematic schema illustrating the main factors influencing PA.

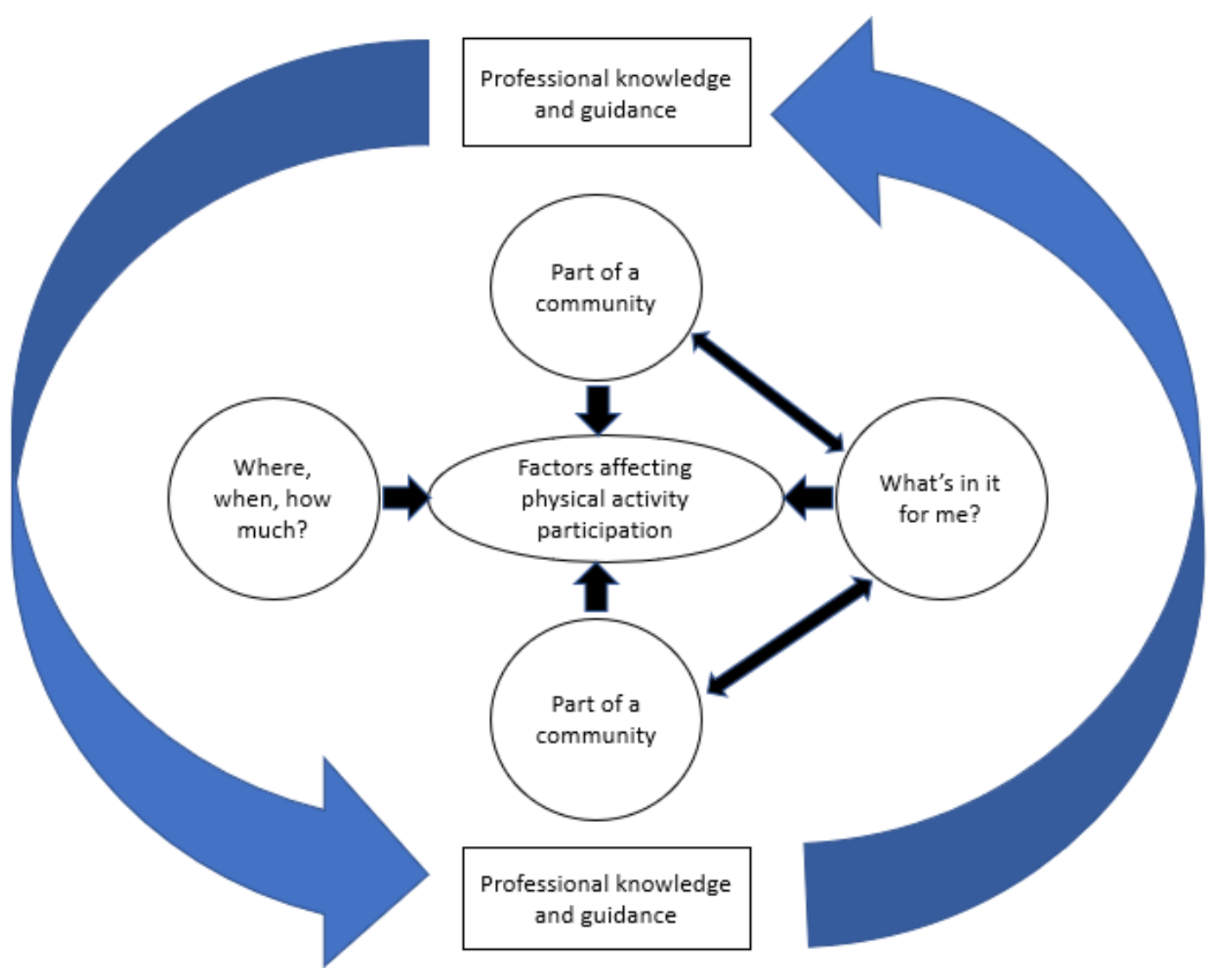


27|P a g e 